\title{
Rapid monitoring of reconstituted Wilms' tumor suppressor gene-specific $t$ lymphocytes after allogeneic stem cell transplantation using quantitative real time Polymerase chain reaction
}

\author{
Ahmad A Ab-Khader*, Stefan Krause, Ernst Holler \\ From Updates on Immunotherapy of Cancer and Immunoscore Symposium, part of the Sidra Symposia Series, \\ held in partnership with the Society for Immunotherapy of Cancer
}

Doha, Qatar. 22-23 January 2014

\section{Background}

Wilms' tumor suppressor gene (WT1) protein is overexpressed in some leukemias and various types of solid tumors, and it is considered to be an attractive target antigen for immunotherapy.

\section{Methods}

After ex vivo stimulation of peripheral blood mononuclear cells (PBMCs) from 12 patients with two HLA-A2 restricted WT1 peptides (Db126 and WH187), between 220 days and 32 months after allogeneic SCT, interferon-gamma (IFN- $\gamma$ ) quantitative real time polymerase chain reaction (qRT-PCR) and ELISPOT assays were used to evaluate WT1 responses in 22 samples.

\section{Results}

Both WT1 antigens induced significant quantities of IFN- $\gamma$ mRNA production after $3 \mathrm{~h}$ in the qRT-PCR protocol. Among 18 samples of HLA-A2+, specific responses were detected in $27.8 \%(5 / 18)$ when Db126 peptide, compared to $16.7 \%(3 / 18)$ in the case of WH187 peptide. On the other hand, no detection $(0 / 18)$ was obtained with ELISPOT, when both WT1 peptides were tested. In four HLA-A2- samples neither qRT-PCR nor ELISPOT detected any reconstituted WT1-reactive T cells in response to both peptides. As a result, the measurement of IFN- $\gamma$ mRNA by qRT-PCR can be used to detect CTL responses $3 \mathrm{~h}$ after WT1 peptides stimulation of PBMCs.

Department of Hematology and Oncology, University Hospital of Regensburg, Regensburg, Germany

\section{Discussion}

In conclusion, qRT-PCR allows rapid monitoring of WT1-reactive CTLs reconstitution after allogeneic SCT using patient's PBMCs.

Published: 24 February 2014

doi:10.1186/2051-1426-2-S1-P3

Cite this article as: Ab-Khader et al:: Rapid monitoring of reconstituted Wilms' tumor suppressor gene-specific $\mathrm{t}$ lymphocytes after allogeneic stem cell transplantation using quantitative real time Polymerase chain reaction. Journal for ImmunoTherapy of Cancer 2014 2(Suppl 1):P3.
Submit your next manuscript to BioMed Central and take full advantage of:

- Convenient online submission

- Thorough peer review

- No space constraints or color figure charges

- Immediate publication on acceptance

- Inclusion in PubMed, CAS, Scopus and Google Scholar

- Research which is freely available for redistribution
() Biomed Central

\section{() Biomed Central}

(c) 2014 Ab-Khader et al; licensee BioMed Central Ltd. This is an Open Access article distributed under the terms of the Creative Commons Attribution License (http://creativecommons.org/licenses/by/2.0), which permits unrestricted use, distribution, and reproduction in any medium, provided the original work is properly cited. 